\title{
Analisis Perbandingan Metode Triple Exponential Smoothing dan Metode Winter Untuk Peramalan Tingkat Hunian Hotel Aston Denpasar
}

\author{
Joshua Dwi Putra Tamasoleng ${ }^{1}$, Ida Bagus Ary Indra Iswara ${ }^{2 *}$ \\ STMIK STIKOM Indonesia \\ Jalan Tukad Pakerisan No. 97 Panjer Denpasar Selatan \\ Corresponding author's e-mail: aryindraiswara@gmail.com
}

\begin{abstract}
Aston Denpasar Hotel is one of the five-star hotels in Bali currently requires forecasting analysis because it has constraints in determining the number of occupancy rates in the next period. The choice of method in forecasting time series largely determines the results of forecasting, so this research is conducted to find the best method of the method to be used. The method used is Triple Exponential Smoothing one parameter from brown and Winter Multiplicative and Additive methods. Based on the analysis of the best method is the Triple Exponential Smoothing one parameter method of brown with the lowest error testing with MAPE that is equal to $23.35 \%$. While the winter multiplicative method was $28.53 \%$ and the winter additive method was $27.38 \%$
\end{abstract}

Kata kunci: Forecasting, Triple Exponential Smoothing brown, Winter Multiplicative, Winter Additive, $M A P E$

Abstrak - Hotel Aston Denpasar adalah salah satu hotel berbintang di Bali saat ini memerlukan analisis peramalan karena memiliki kendala dalam menentukan jumlah tingkat hunian pada periode berikutnya. Pemilihan metode dalam peramalan time series sangat menentukan hasil peramalan yang diraih, maka dari itu penelitian ini dilakukan untuk mencari metode terbaik dari metode yang akan dipakai. Metode yang dipakai yaitu Triple Exponential Smoothing satu parameter dari brown dan metode Winter Multiplicative dan Additive. Berdasarkan hasil analisis metode yang terbaik adalah metode Triple Exponential Smoothing satu parameter dari brown dengan pengujian error dengan MAPE yang paling rendah yaitu sebesar 23,35 \%. Sedangkan metode winter multiplicative sebesar $28,53 \%$ dan metode winter additive sebesar 27,38\%

Kata Kunci - Peramalan, Triple Exponential Smoothing brown, Winter Multiplicative, Winter Additive, MAPE

\section{Pendahuluan}

Peramalan dapat digunakan sebagai dasar dalam proses pengambilan keputusan untuk piihak manajemen karena memberikan informasi terhadap permintaan di masa mendatang dengan tujuannya adalah untuk menentukan persedian dan budget yang diperlukan[1].

Salah satu metode yang dikembangkan saat ini adalah metode Time Series. Time Series adalah metode yang melakukan pendekatan kuantitatif pada data yang ada pada masa lalu. Proses peramalan saat ini sudah digunakan oleh berbagai macam jenis usaha, baik itu produksi maupun jasa. Salah satu perusahaan yang bergerak dalam bidang jasa adalah hotel.

Hotel Aston adalah salah satu hotel yang selalu dikunjungi wisatawan manca negara dan wisatawan lokal. Maka dari itu hotel ini seharusnya melakukan segala macam perencanaan untuk dasar tindakan yang dilakukan di masa depan. Dengan adanya perencanaan maka hotel memerlukan prediksi atau peramalan untuk memperkirakan apa yang akan terjadi di masa mendatang. Peramalan yang biasa dilakukan untuk hotel adalah peramalan tingkat Hunian.

Peramalan tingkat hunian yaitu sebagai kunci kesukesesan hotel dalam bidang pendapatan. Data tingkat hunian dari periode sebelumnya bisa menjadi gambaran perkembangan jumlah pengunjung. Peramalan tingkat hunian sangat berguna untuk pihak manajemen dalam mempersiapkan segala sesuatu seperti budget dan melakukan evaluasi pelayanan.[2]

Akan tetapi untuk menghasilkan peramalan yang baik diperlukan pemilihan metode yang sesuai kebutuhan. Maka dari itu perlu membandingan metode satu dengan metode yang lainnya agar mendapatkan hasil akurasi peramalan yang terbaik. Berbagai penelitian telah mengusulkan metode untuk menyelesaiakan peramalan time series contohnya adalah triple exponential smoothing satu parameter dari brown untuk data yang memiliki pola tren kuadratik dan winter untuk data yang memiliki pola musiman.

Pada dasarnya metode-metode tersebut memiliki tujuan yang sama yaitu untuk melakukan prediksi kejadian di masa depan dengan menggunakan data pada masa lalu sebagai panduan dalam perhitungannya. Maka dalam penelitian ini akan membandingan metode apa yang terbaik untuk peramalan tingkat hunian Hotel Aston Denpasar. 


\section{Metode Penelitian}

Metode pengumpulan data pada penelitian ini adalah dari studi pustaka dengan cara mengkaji sejumlah literatur secara mendalam yang berupa buku, skripsi, dan informasi yang berkaitan dengan masalah sehingga muncul ide dalam pengembangan dalam upaya pemecahan masalah. Data diperoleh dari sumber BPS Denpasar yaitu tingkat hunian hotel aston tahun 2014 - 2018. Selain itu juga melakukan wawancara terhadap karawan hotel Aston Denpasar untuk mendapatkan informasi mengenai tingkat hunian.

Pada penelitian ini dalam melakukan analisis data yang diperoleh menggunakan Microsoft Excel. Sementara metode yang digunakan dalam perhitungan peramalannya adalah triple exponential smoothing satu parameter dari brown dan metode winter multiplicative dan winter additive.

1. Triple Exponential Smoothing satu parameter dari brown adalah metode yang digunakan untuk meramalkan data dengan pola tren kuadratik yang pola datanya bersifat fluktuasi dan mengalami gelombang pasang surut.[3] Dalam perhitungan peramalan metode ini melakukan pemulusan sebanyak tiga kali seperti rumus sebagai berikut :

$$
\begin{aligned}
& S_{t}^{\prime}=a X t(1-a) \\
& S^{\prime \prime}{ }_{t}=a S^{\prime} t+(1-a){S^{\prime \prime}}_{t-1} \\
& S^{\prime \prime \prime}{ }_{t}=a S^{\prime \prime} t+(1-a) S^{\prime \prime \prime}{ }_{t-1} \\
& a_{t}=3{S^{\prime}}_{t}-3{S^{\prime \prime}}_{t}+S^{\prime \prime \prime}{ }_{t-1} \\
& b_{t}=\frac{a^{2}}{2(1-a)^{2}}\left[(6-5 a) S^{\prime}-(10-8 a) S^{\prime \prime}{ }_{t}+(4-3 a) S^{\prime \prime \prime}{ }_{t}\right] \\
& c_{t}=\frac{a^{2}}{(1-a)^{2}}\left(S_{t}^{\prime}{ }_{t}-2{S^{\prime \prime}}_{t}+{S^{\prime \prime \prime}}_{t}\right) \\
& F_{t}=a_{t}+b_{t}+\frac{1}{2} C_{t}
\end{aligned}
$$

Keterangan :

$$
\begin{aligned}
& S_{t}^{t}=\text { Nilai Pemulusan Pertama } \\
& S^{\prime I}{ }_{t}=\text { Nilai Pemulusan Kedua } \\
& S^{\prime \prime I}{ }_{t}=\text { Nilai Pemulusan Ketiga } \\
& a_{t}=\text { Nilai Rata - Rata Periode } \\
& b_{t}=\text { Nilai Trend Linear } \\
& c_{t}=\text { Nilai Trend Parabolik } \\
& F_{t}=\text { Peramalan }
\end{aligned}
$$

2. Winter adalah metode yang didasarkan pada tiga persamaan pemulusan stasioner, trend dan musiman. Metode ini dipakai jika ada pola musiman dalam data. Metode winter terdiri dari winter multiplicative dan winter additive. Winter multiplicative fluktuasi musimannya bersifat meningkat sering berjalannya periode. Sedangkan winter additive tetap. [4]. Berikut ini adalah rumus perhitungan peramalan menggunakan metode Winter Multiplicative :

$$
\begin{aligned}
& L_{t}=a \frac{X t}{S_{t+-}}+(1-a)\left(L_{t-1}+b_{t-1}\right) \\
& b_{t}=\beta\left(L_{t}-L_{t-1}\right)+(1-\beta) b_{t-1} \\
& S_{t}=\gamma \frac{X_{t}}{L_{t}}+(1-\gamma) S_{t-s} \\
& F_{t+m}=\left(L_{t}+b_{t} m\right) S_{t-s+m}
\end{aligned}
$$

Berikut ini adalah rumus perhitungan peramalan Winter Additive :

$$
\begin{aligned}
& L_{t}=a\left(X_{t}-S_{t-s}\right)+(1-a)\left(L_{t-1}+b_{t-1}\right) \\
& b_{t}=\beta\left(L_{t}-L_{t-1}\right)+(1-\beta) b_{t-1}
\end{aligned}
$$


$S_{t}=\gamma\left(X_{t}-L_{t}\right)+(1-\gamma) S_{t-s}$

$F_{t+m}=L_{t}+b_{t} m+S_{t-s+m}$

Keterangan :

$L_{t}=$ Pemulusan Level

$b_{t=\text { Pemulusan Trend }}$

$S_{t=\text { Pemulusan Musiman }}$

$F_{t+m}=$ Peramalan untuk periode ke depan.

3. Ketepatan Metode Peramalan

Ketepatan metode peramalan digunakan untuk menunjukan seberapa baik dan seberapa tepat peramalan tersebut dengan kesalahannya terhadap data aktual.[5]. Terdapat ukuran ketepatan peramalan sebagai berikut :

Mean Absolute Percentage Error (MAPE) adalah metode yang digunakan untuk melakukan perhitungan ketepatan metode peramalan. MAPE dihitung dengan menggunakan kesalahan absolut yang dibagi dengan data aktual pada periode tersebut, kemudia dirata ratakan. [6]. Berikut ini adalah rumus perhitungannya:

$$
\text { MAPE }=\frac{\sum \frac{[\text { Actual }- \text { forecast }] * 100}{\text { Actual }}}{n}
$$

\section{Hasil dan Pembahasan}

Data yang dianalisa dalam penelitian ini adalah data kuantitatif dari tingkat hunian dalam kurun waktu 60 periode atau 5 tahun. Sebagai langkah awal penelitian akan menyajikan grafik dari data aktual untuk melihat pola yang ada pada trend dan musim dari data aktual sebagai berikut.

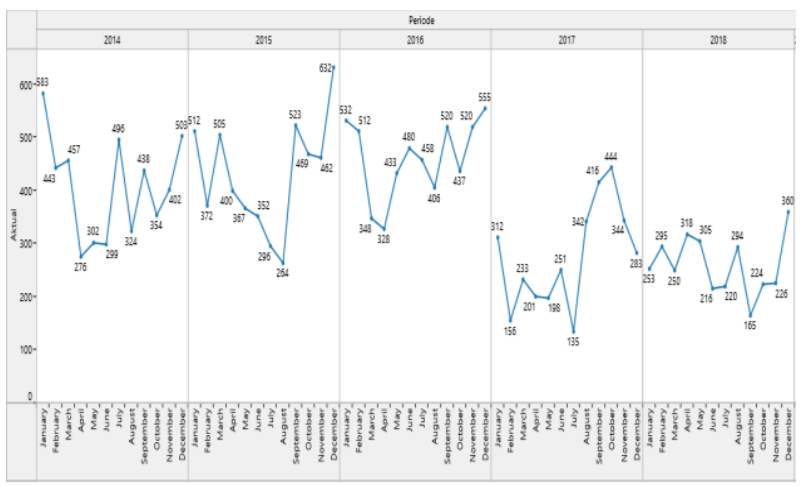

Gambar 1 Pola Data Aktual

Dari data tersebut selanjutnya akan dilakukan perhitungan peramalan dengan metode triple exponential smoothing dan winter.

A. Peramalan Menggunakan Metode Triple Exponential Smoothing satu parameter dari brown

Pada metode ini tahapan yang akan dilakukan adalah sebagai berikut :

a. Menentukan inisialisasi nilai awal

Inisialisasi dilakukan karena pada rumus peramalan memerlukan data pada periode sebelumnya, akan tetapi jika yang kita hitung adalah data pertama maka kita harus melakukan inisialisasi.

$$
\begin{aligned}
& S_{1}^{\prime}=S^{\prime \prime}{ }_{1}=S^{\prime \prime \prime}{ }_{1}=X_{1} \\
& a_{1}=X_{1} \\
& b_{1}=\frac{\left(X_{2}-X_{1}\right)+\left(X_{2}-X_{2}\right)+\left(X_{4}-X_{2}\right)}{3} \\
& c_{1}=\frac{\left(X_{1}-X_{1}\right)}{2}
\end{aligned}
$$


Perhitungan inisialisasi

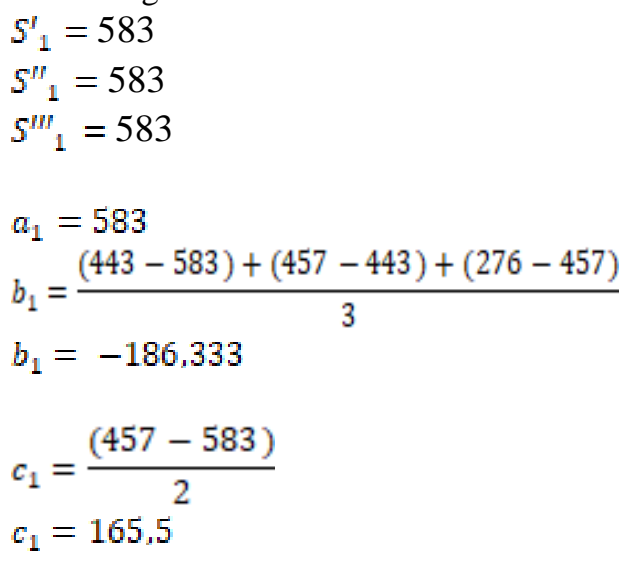

Setelah melakukan perhitungan inisialisasi nilai awal, selanjutnya melakukan penentuan nilai parameter $\alpha$. Cara menentukan nilai parameter $\alpha$ terbaik dengan melakukan trial and error. Nilai parameter $\alpha$ yang digunakan oleh penelitian ini adalah 0,39297.

b. Perhitungan Peramalan

Selanjutnya melakukan peramalan dengan menggunakan parameter $\alpha 0,39297$ adalah sebagai berikut. Peramalan dilakukan dari periode ke 2.

\section{Nilai Pemulusan Pertama}

$S_{t}^{\prime}=a X t+(1-a) S_{t-1}^{\prime}$

$S_{2}^{\prime}=(0,39297) 443+(1-0,39297) 583$

$S_{2}^{\prime}=527,98$

Nilai Pemulusan pertama dilakukan sampai periode terakhir dengan cara yang sama seperti di atas.

\section{Nilai Pemulusan Kedua}

$S^{\prime \prime}{ }_{t}=a S^{\prime} t+(1-a) S^{\prime \prime}{ }_{t-1}$

$S^{\prime \prime}{ }_{2}=(0,39297) 569+(1-0,39297) 583$

$S^{\prime \prime}{ }_{2}=561,38$

Nilai pemulusan kedua dilakukan sampai periode terakhir dengan cara yang sama seperti di atas.

Nilai Pemulusan Ketiga

$S^{\prime \prime \prime}{ }_{t}=a S^{\prime \prime} t+(1-a) S^{\prime \prime \prime}{ }_{t-1}$

$S^{\prime \prime \prime}{ }_{2}=(0,39297) 581,6+(1-0,39297) 583$

$S^{\prime \prime \prime}{ }_{2}^{2}=574,50$

Nilai pemulusan ketiga dilakukan sampai periode terakhir dengan cara yang sama di atas.

\section{Nilai Rata - Rata Periode}

$a_{t}=3 S_{t}^{\prime}-3 S^{\prime \prime}{ }_{t}+S^{\prime \prime \prime}{ }_{t-1}$

$a_{2}=3 \times 527,98-3 \times 561,38+574,50$

$a_{2}=482,81$

Nilai rata-rata periode dilakukan sampai periode terakhir dengan cara yang sama di atas.

Nilai Tren Linear (Kecenderungan)

$$
\begin{gathered}
b_{2}=\frac{0,39297^{2}}{2(1-0,39297)^{2}}[(6-5 \times 0,39297) 527,98-(10-8 \times 0,39297) 561,38 \\
\quad+(4-3 \times 0,39297) 574,50]
\end{gathered}
$$


Nilai tren linear dilakukan sampai periode terakhir dengan cara yang sama seperti di atas.

\section{Nilai Tren Parabolik}

$$
\begin{gathered}
c_{t}=\frac{a^{2}}{(1-a)^{2}}\left(S^{\prime}{ }_{t}-2 S^{\prime \prime}{ }_{t}+S^{\prime \prime \prime}{ }_{t}\right) \\
c_{2}=\frac{0,39297^{2}}{(1-0,39297)^{2}}(527,98-2 \times 561,38+574,50) \\
c_{2}=-8,50
\end{gathered}
$$

Nilai tren parabolic dilakukan sampai periode terkakhir dilakukan dengan cara yang sama seperti di atas.

\section{Peramalan}

$$
\begin{aligned}
& F_{3}=482,81+(-2,78)+\frac{1}{2}(-8,50) \\
& F_{3}=475,78
\end{aligned}
$$

Perhitungan peramalan dilakukan sampai periode $\mathrm{n}$ yang dilakukan dengan cara yang sama seperti di atas. Untuk peramalan pada periode terakhir untuk bulan Januari 2019 adalah sebesar 335. Berikut ini adalah perbandingan grafik data aktual dengan peramalan.

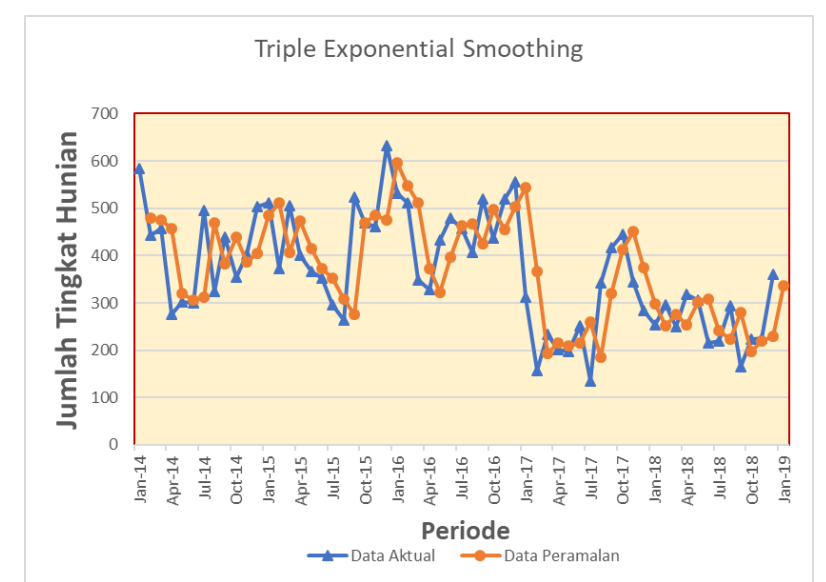

Gambar 2 Grafik Triple Exponential Smoothing satu parameter

B. Evaluasi Hasil Peramalan Metode Triple Exponential Smoothing satu parameter brown Untuk menguji ketepataan peramalan menggunakan MAPE dengan perhitunga sebagai berikut

$$
\begin{aligned}
& \text { Absolute Percentage Error }(P E)=A B S\left(\frac{X_{t}-F_{t}}{X_{t}}\right) \times 100 \\
& \text { Absolute Percentage Error }\left(P E_{2}\right)=A B S\left(\frac{443-479}{443}\right) \times 100 \\
& \text { Absolute Percentage Error }\left(P E_{2}\right)=8,22 \\
& M A P E=\left(\frac{\sum A P E}{n}\right) \\
& M A P E=\left(\frac{1377}{59}\right) \\
& M A P E=\mathbf{2 3 , 3 5 1 7 \%}
\end{aligned}
$$


Jurnal Nasional Komputasi dan Teknologi Informasi

Vol. 3 No. 1, April 2020

P-ISSN 2620-8342

E-ISSN 2621-3052

Berikut ini adalah hasil peramalan dengan error dari metode triple exponential smoothing satu parameter dari brown.

Tabel 1 Peramalan Triple Exponential Smoothing satu parameter dari brown

\begin{tabular}{|c|c|c|c|c|}
\hline $\mathrm{P}$ & Aktual & $\mathrm{Ft}$ & Error & Persentase Error \\
\hline 1 & 583 & & & \\
\hline 2 & 443 & 479,42 & 36,42 & 8,22 \\
\hline 3 & 457 & 475,78 & 18,78 & 4,11 \\
\hline 4 & 276 & 457,37 & 181,37 & 65,71 \\
\hline 5 & 302 & 319,73 & 17,73 & 5,87 \\
\hline 6 & 299 & 306,88 & 7,88 & 2,63 \\
\hline 7 & 496 & 311,22 & 184,78 & 37,25 \\
\hline 8 & 324 & 469,49 & 145,49 & 44,91 \\
\hline 9 & 438 & 383,14 & 54,86 & 12,53 \\
\hline 10 & 354 & 438,10 & 84,10 & 23,76 \\
\hline 11 & 402 & 386,67 & 15,33 & 3,81 \\
\hline 12 & 503 & 404,24 & 98,76 & 19,63 \\
\hline 13 & 512 & 485,34 & 26,66 & 5,21 \\
\hline 14 & 372 & 512,27 & 140,27 & 37,71 \\
\hline 15 & 505 & 406,31 & 98,69 & 19,54 \\
\hline 16 & 400 & 474,02 & 74,02 & 18,51 \\
\hline 17 & 367 & 414,87 & 47,87 & 13,04 \\
\hline 18 & 352 & 371,94 & 19,94 & 5,66 \\
\hline 19 & 296 & 351,41 & 55,41 & 18,72 \\
\hline 20 & 264 & 307,28 & 43,28 & 16,39 \\
\hline 21 & 523 & 274,73 & 248,27 & 47,47 \\
\hline 22 & 469 & 469,00 & 0,00 & 0,00 \\
\hline 23 & 462 & 484,83 & 22,83 & 4,94 \\
\hline 24 & 632 & 475,00 & 157,00 & 24,84 \\
\hline 25 & 532 & 595,57 & 63,57 & 11,95 \\
\hline 26 & 512 & 547,88 & 35,88 & 7,01 \\
\hline 27 & 348 & 510,71 & 162,71 & 46,76 \\
\hline 28 & 328 & 372,71 & 44,71 & 13,63 \\
\hline 29 & 433 & 321,48 & 111,52 & 25,76 \\
\hline 30 & 480 & 397,60 & 82,40 & 17,17 \\
\hline \multicolumn{5}{|c|}{$\ldots \ldots$} \\
\hline 60 & 360 & 229,48 & 130,52 & 36,26 \\
\hline 61 & & 335,33 & & \\
\hline
\end{tabular}

Selanjutnya melakukan proses perhitungan peramalan dengan metode winter multiplicative

C. Peramalan Menggunakan Metode Winter Multiplicative

Pada metode ini tahapan yang akan dilakukan adalah sebagai berikut :

a. Menentukan inisialisasi nilai awal 
Inisialisasi dilakukan karena pada rumus peramalan memerlukan data pada periode sebelumnya, akan tetapi jika yang kita hitung adalah data pertama maka kita harus melakukan inisialisasi. Pada metode winter multiplicative inisialisasi dilakukan untuk satu musim awal. Pada penelitian ini 1 musim awal adalah selama setahun atau 12 bulan. Proses perhitungan Inisialisasi adalah sebagai berikut :

Inisialisasi Level

$$
\begin{aligned}
& L_{s}=\frac{1}{s}\left(X_{1}+X_{2}+X_{3} \ldots+X_{s}\right) \\
& L_{12}=\frac{1}{12}\left(X_{1}+X_{2}+X_{3} \ldots+X_{12}\right) \\
& L_{12}=406,4167
\end{aligned}
$$

$$
\begin{aligned}
& \quad \begin{array}{l}
\text { Inisialisasi Tren } \\
B_{s}=
\end{array} \frac{1}{s}\left[\frac{X_{s+1}-X_{1}}{s}+\frac{X_{s+2}-X_{2}}{s}+\cdots+\frac{X_{s+s}-X_{s}}{s}\right] \\
& B_{12}=\frac{1}{12}\left[\frac{X_{12+1}-X_{1}}{12}+\frac{X_{12+2}-X_{12}}{12}+\cdots+\frac{X_{12+12}-X_{12}}{12}\right] \\
& B_{12}=\frac{1}{12}\left[\frac{X_{12+1}-X_{1}}{12}+\frac{X_{12+2}-X_{12}}{12}+\cdots+\frac{X_{12+12}-X_{12}}{12}\right] \\
& B_{12}=1,923611
\end{aligned}
$$

$$
\begin{aligned}
& \text { Inisialisasi Musiman } \\
& S_{1}=\frac{X_{1}}{L_{x}}, S_{2}=\frac{X_{2}}{L_{x}}, \ldots \ldots S_{s}=\frac{X_{n}}{L_{m}}, \\
& S_{1}=\frac{583}{406,4}=1,43 \\
& S_{2}=\frac{443}{406,4}=1,09 \\
& S_{\mathrm{a}}=\frac{457}{406,4}=1,12 \\
& S_{4}=\frac{276}{406,4}=0,67 \\
& \ldots . . \\
& S_{12}=\frac{503}{406,4}=1,23
\end{aligned}
$$

Setelah melakukan perhitungan inisialisasi nilai awal, selanjutnya melakukan penentuan nilai parameter $\alpha, \beta, \gamma$. Cara menentukan nilai parameter terbaik dengan melakukan trial and error. Nilai parameter $\alpha$ yang digunakan oleh penelitian ini adalah 0,396 untuk parameter $\beta$ adalah 0,1 dan untuk $\gamma$ adalah 0,7516 .

b. Perhitungan Peramalan

Perhitungan dilakukan dari periode ke 13 atau pada musim berikutnya. Perhitungannya sebagai berikut.

\section{Perhitungan Level}

$$
\begin{aligned}
& L_{t}=a \frac{X t}{S_{t-s}}+(1-a)\left(L_{t-1}+b_{t-1}\right) \\
& L_{13}=0,396 \frac{512}{1,43}+(1-0,396)(406,41+1,92)=387,9932
\end{aligned}
$$


Perhitungan akan dilakukan sampai periode ke-n yang akhir.

\section{Perhitungan Tren}

$b_{t}=\beta\left(L_{t}-L_{t-1}\right)+(1-\beta) b_{t-1}$

$b_{13}=0,1(387,99-406,41)+(1-0,1) 1,923=-0,11$

Perhitungan akan dilakukan sampai periode ke-n yang akhir.

\section{Perhitungan Musiman}

$$
\begin{aligned}
& S_{t}=\gamma \frac{X_{t}}{L_{t}}+(1-\gamma) S_{t-s} \\
& S_{13}=0,7516 \frac{512}{387,99}+(1-0,7516) 1,43=1,237
\end{aligned}
$$

Perhitungan akan dilakukan sampai periode ke-n yang akhir.

$$
\begin{aligned}
& \text { Peramalan } \\
& F_{t+m}=\left(L_{t}+b_{t} m\right) S_{t-s+m} \\
& F_{12+1}=\left(L_{12}+b_{12} 1\right) S_{12-12+1} \\
& F_{13}=\left(L_{12}+b_{12}\right) S_{1} \\
& F_{13}=(406,41+1,923) 1,43=585,759
\end{aligned}
$$

Perhitungan peramalan dilakukan sampai periode $n$ yang dilakukan dengan cara yang sama seperti di atas. Untuk peramalan pada periode terakhir untuk bulan Januari 2019 adalah sebesar 230 orang. Berikut ini adalah perbandingan grafik data aktual dengan peramalan.

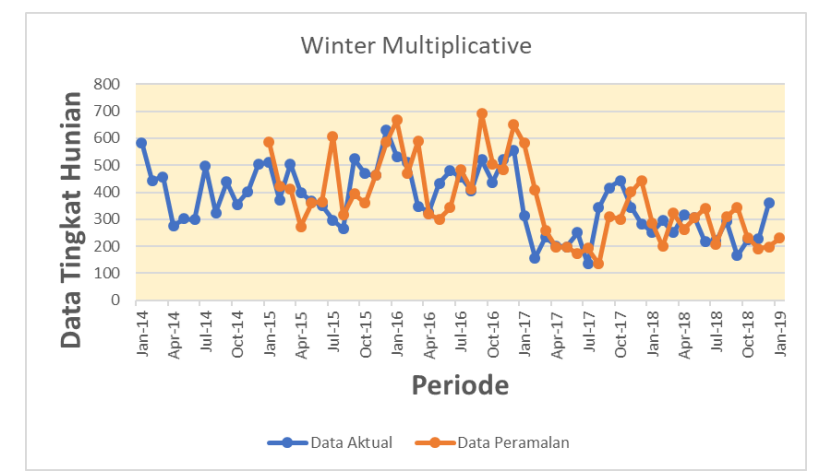

Gambar 3 Grafik Winter Multiplicative

D. Evaluasi Hasil Peramalan Metode Winter Multiplicative

Untuk menguji ketepataan peramalan menggunakan MAPE dengan perhitunga sebagai berikut

Absolute Percentage Error $(P E)=A B S\left(\frac{X_{t}-F_{t}}{X_{t}}\right) \times 100$
Absolute Percentage Error $\left(P E_{13}\right)=\left(\frac{512-585,76}{512}\right) \times 100$
Absolute Percentage Error $\left(P E_{13}\right)=14,41$

$M A P E=\left(\frac{\sum A P E}{n}\right)$

$M A P E=\left(\frac{1369,60}{59}\right)$

$M A P E=28,53 \%$

Berikut ini adalah hasil peramalan dengan error dari metode winter multiplicative . 
Tabel 2 Peramalan Winter Multiplicative

\begin{tabular}{|c|c|c|c|c|}
\hline $\mathrm{P}$ & Aktual & $\mathrm{Ft}$ & Error & Persentase Error \\
\hline 1 & 583 & & & \\
\hline 2 & 443 & & & \\
\hline 3 & 457 & & & \\
\hline 4 & 276 & & & \\
\hline 5 & 302 & & & \\
\hline 6 & 299 & & & \\
\hline 7 & 496 & & & \\
\hline 8 & 324 & & & \\
\hline 9 & 438 & & & \\
\hline 10 & 354 & & & \\
\hline 11 & 402 & & & \\
\hline 12 & 503 & & & \\
\hline 13 & 512 & 585,76 & 73,76 & 14,41 \\
\hline 14 & 372 & 422,80 & 50,80 & 13,66 \\
\hline 15 & 505 & 413,22 & 91,78 & 18,17 \\
\hline 16 & 400 & 272,36 & 127,64 & 31,91 \\
\hline 17 & 367 & 359,76 & 7,24 & 1,97 \\
\hline 18 & 352 & 365,71 & 13,71 & 3,90 \\
\hline 19 & 296 & 607,87 & 311,87 & 105,36 \\
\hline 20 & 264 & 315,06 & 51,06 & 19,34 \\
\hline 21 & 523 & 393,98 & 129,02 & 24,67 \\
\hline 22 & 469 & 360,08 & 108,92 & 23,22 \\
\hline 23 & 462 & 463,19 & 1,19 & 0,26 \\
\hline 24 & 632 & 585,60 & 46,40 & 7,34 \\
\hline 25 & 532 & 667,10 & 135,10 & 25,39 \\
\hline 26 & 512 & 470,67 & 41,33 & 8,07 \\
\hline 27 & 348 & 587,84 & 239,84 & 68,92 \\
\hline 28 & 328 & 318,74 & 9,26 & 2,82 \\
\hline 29 & 433 & 299,69 & 133,31 & 30,79 \\
\hline 30 & 480 & 342,88 & 137,12 & 28,57 \\
\hline \multicolumn{5}{|c|}{$\cdots \cdot$} \\
\hline 60 & 360 & 197,94 & 162,06 & 45,02 \\
\hline 61 & & 230,27 & & \\
\hline
\end{tabular}

Selanjutnya melakukan proses perhitungan peramalan dengan metode winter additive.

\section{E. Peramalan Menggunakan Metode Winter Additive}

Pada metode ini tahapan yang akan dilakukan adalah sebagai berikut :

a. Menentukan inisialisasi nilai awal

Inisialisasi dilakukan karena pada rumus peramalan memerlukan data pada periode sebelumnya, akan tetapi jika yang kita hitung adalah data pertama maka kita harus melakukan inisialisasi. Pada metode winter additive 
inisialisasi dilakukan untuk satu musim awal. Pada penelitian ini 1 musim awal adalah selama setahun atau 12 bulan. Proses perhitungan Inisialisasi adalah sebagai berikut :

Inisialisasi Level

$$
\begin{aligned}
& L_{s}=\frac{1}{s}\left(X_{1}+X_{2}+X_{3} \ldots+X_{s}\right) \\
& L_{12}=\frac{1}{12}\left(X_{1}+X_{2}+X_{3} \ldots+X_{12}\right) \\
& L_{12}=406,4167
\end{aligned}
$$

Inisialisasi Tren

$$
\begin{aligned}
& B_{s}=\frac{1}{s}\left[\frac{X_{s+1}-X_{1}}{s}+\frac{X_{s+2}-X_{2}}{s}+\cdots+\frac{X_{s+s}-X_{s}}{s}\right] \\
& B_{12}=\frac{1}{12}\left[\frac{X_{12+1}-X_{1}}{12}+\frac{X_{12+2}-X_{12}}{12}+\cdots+\frac{X_{12+12}-X_{12}}{12}\right] \\
& B_{12}=\frac{1}{12}\left[\frac{X_{12+1}-X_{1}}{12}+\frac{X_{12+2}-X_{12}}{12}+\cdots+\frac{X_{12+12}-X_{12}}{12}\right] \\
& B_{12}=1,923611
\end{aligned}
$$

Inisialisasi Musiman

$$
\begin{aligned}
& S_{1}=X_{1}-L_{s}, S_{2}=X_{2}-L_{s}, \ldots S_{s}=X_{s}-L_{s} \\
& S_{1}=583-406,4=176,58 \\
& S_{2}=443-406,4=36,58 \\
& S_{3}=457-406,4=50,58 \\
& S_{4}=276-406,4=-130,41 \\
& \ldots \\
& S_{12}=503-406,4=96,58
\end{aligned}
$$

Setelah melakukan perhitungan inisialisasi nilai awal, selanjutnya melakukan penentuan nilai parameter $\alpha, \beta, \gamma$. Cara menentukan nilai parameter terbaik dengan melakukan trial and error. Nilai parameter $\alpha$ yang digunakan oleh penelitian ini adalah 0,402 untuk parameter $\beta$ adalah 0,1 dan untuk $\gamma$ adalah 0,805 .

b. Perhitungan Peramalan

Perhitungan dilakukan dari periode ke 13 atau pada musim berikutnya. Perhitungannya sebagai berikut.

\section{Perhitungan Level}

$$
\begin{aligned}
& L_{t}=a\left(X_{t}-S_{t-s}\right)+(1-a)\left(L_{t-1}+b_{t-1}\right) \\
& L_{13}=0,402(512-176,58)+(1-0,402)(406,41+1,92)=378,99
\end{aligned}
$$

Perhitungan akan dilakukan sampai periode ke-n yang akhir.

\section{Perhitungan Tren}

$$
\begin{gathered}
b_{t}=\beta\left(L_{t}-L_{t-1}\right)+(1-\beta) b_{t-1} \\
b_{13}=0,1(378,99-406,41)+(1-0,1) 1,92=-1,01
\end{gathered}
$$

Perhitungan akan dilakukan sampai periode ke-n yang akhir.

\section{Perhitungan Musiman}

$$
\begin{aligned}
& S_{t}=\gamma\left(X_{t}-L_{t}\right)+(1-\gamma) S_{t-s} \\
& S_{13}=0,805(512-378,99)+(1-0,805) 176,583=141,48
\end{aligned}
$$

Perhitungan akan dilakukan sampai periode ke-n yang akhir.

\section{Peramalan}


$F_{t+m}=L_{t}+b_{t} m+S_{t-s+m}$

$F_{12+1}=L_{12}+b_{12} 1+S_{12-12+1}$

$F_{13}=L_{12}+b_{12}+S_{1}$

$F_{13}=406,41+1,92+176,58=584,92$

Perhitungan peramalan dilakukan sampai periode $\mathrm{n}$ yang dilakukan dengan cara yang sama seperti di atas. Untuk peramalan pada periode terakhir untuk bulan Januari 2019 adalah sebesar 214. Berikut ini adalah perbandingan grafik data aktual dengan peramalan.

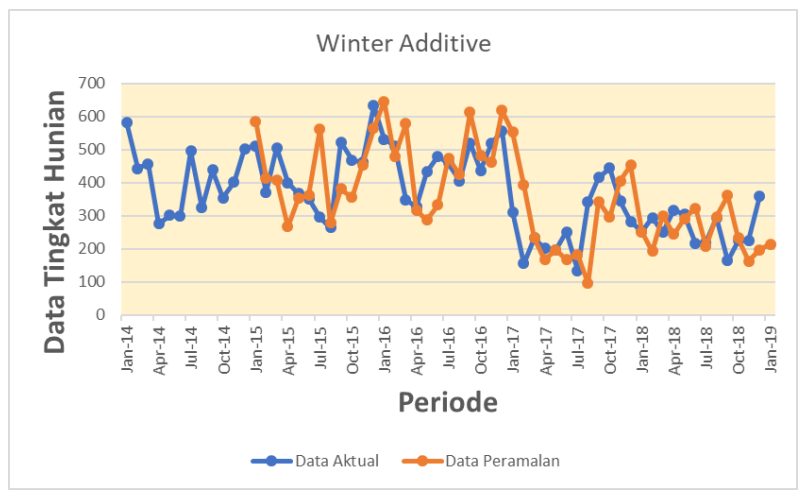

Gambar 4 Grafik Winter Additive

F. Evaluasi Hasil Peramalan Metode Winter Additive

Untuk menguji ketepataan peramalan menggunakan MAPE dengan perhitunga sebagai berikut.

Absolute Percentage Error $(P E)=A B S\left(\frac{X_{t}-F_{t}}{X_{t}}\right) \times 100$

Absolute Percentage Error $\left(P E_{13}\right)=\left(\frac{512-584,92}{512}\right) \times 100$

Absolute Percentage Error $\left(P E_{13}\right)=14,41$

$$
\begin{aligned}
& M A P E=\left(\frac{\sum A P E}{n}\right) \\
& M A P E=\left(\frac{1314,45}{59}\right) \\
& M A P E=\mathbf{2 7}, 384 \%
\end{aligned}
$$

Berikut ini adalah hasil peramalan dengan error dari metode winter additive

Tabel 3 Peramalan Winter Additive

\begin{tabular}{|c|c|c|c|c|}
\hline P & Aktual & Ft & Error & Persentase Error \\
\hline 1 & 583 & & & \\
\hline 2 & 443 & & & \\
\hline 3 & 457 & & & \\
\hline 4 & 276 & & & \\
\hline 5 & 302 & & & \\
\hline 6 & 299 & & & \\
\hline 7 & 496 & & & \\
\hline 8 & 324 & & & \\
\hline 9 & 438 & & & \\
\hline
\end{tabular}




\begin{tabular}{|c|c|c|c|c|}
\hline $\mathrm{P}$ & Aktual & $\mathrm{Ft}$ & Error & Persentase Error \\
\hline 10 & 354 & & & \\
\hline 11 & 402 & & & \\
\hline 12 & 503 & & & \\
\hline 13 & 512 & 584,92 & 72,92 & 14,24 \\
\hline 14 & 372 & 414,57 & 42,57 & 11,44 \\
\hline 15 & 505 & 408,72 & 96,28 & 19,07 \\
\hline 16 & 400 & 267,61 & 132,39 & 33,10 \\
\hline 17 & 367 & 353,35 & 13,65 & 3,72 \\
\hline 18 & 352 & 362,87 & 10,87 & 3,09 \\
\hline 19 & 296 & 562,09 & 266,09 & 89,89 \\
\hline 20 & 264 & 278,91 & 14,91 & 5,65 \\
\hline 21 & 523 & 382,19 & 140,81 & 26,92 \\
\hline 22 & 469 & 355,80 & 113,20 & 24,14 \\
\hline 23 & 462 & 454,85 & 7,15 & 1,55 \\
\hline 24 & 632 & 564,52 & 67,48 & 10,68 \\
\hline 25 & 532 & 645,07 & 113,07 & 21,25 \\
\hline 26 & 512 & 478,14 & 33,86 & 6,61 \\
\hline 27 & 348 & 577,92 & 229,92 & 66,07 \\
\hline 28 & 328 & 317,86 & 10,14 & 3,09 \\
\hline 29 & 433 & 287,26 & 145,74 & 33,66 \\
\hline 30 & 480 & 333,44 & 146,56 & 30,53 \\
\hline \multicolumn{5}{|c|}{$\ldots .}$. \\
\hline 60 & 360 & 197,14 & 162,86 & 45,24 \\
\hline 61 & & 214,80 & & \\
\hline
\end{tabular}

Selanjutnya menampilkan perbandingan grafik peramalan dari metode yang ada.

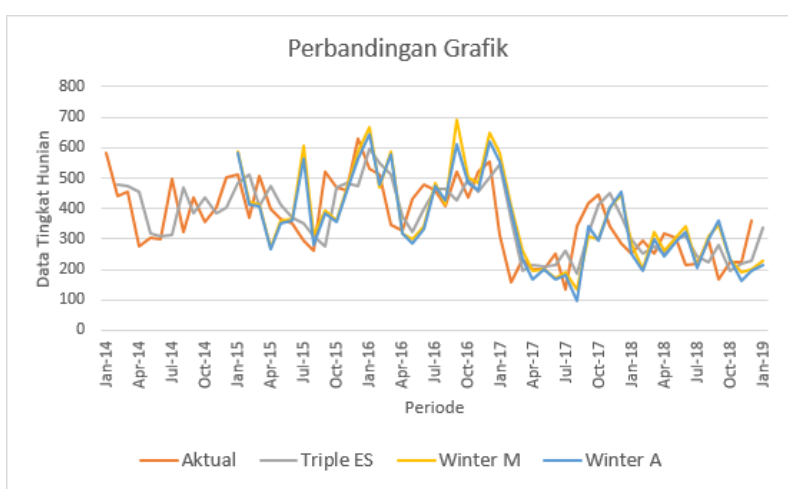

Gambar 5 Perbandingan Grafik Peramalan

Selanjutnya menampilkan perbedaan MAPE dari masing masing metode sebagai berikut.

Tabel 4 Perbandingan MAPE

\begin{tabular}{|l|l|}
\hline Metode & MAPE \\
\hline $\begin{array}{l}\text { Triple Exponential } \\
\text { Smoothing satu }\end{array}$ & $\mathbf{2 3 , 3 5 \%}$ \\
\hline
\end{tabular}




\begin{tabular}{|l|c|}
\hline parameter & \\
\hline $\begin{array}{l}\text { Winter } \\
\text { Multiplicative }\end{array}$ & $28,53 \%$ \\
\hline Winter Additive & $27,38 \%$ \\
\hline
\end{tabular}

Dapat disimpulkan bahwa metode Triple Exponential Smoothing satu parameter dari brown adalah metode terbaik untuk melakukan peramalan pada data tingkat hunian hotel aston Denpasar karena memiliki evaluasi hasil peramalan MAPE yang lebih kecil daripada metode Winter Multiplicative dan Winter additive

\section{Kesimpulan}

Setelah menyelesaikan penelitian dengan analisis, berikut ini adalah kesimpulan yang didapatkan:

1. Setelah dilakukan perhitungan terhadap metode Triple Exponential Smoothing satu parameter dan metode Winter untuk data tingkat hunian hotel Aston Denpasar periode Januari 2014 - Desember 2018 diperoleh nilai yang mendekati nilai aktual yaitu metode Triple Exponential Smoothing satu parameter yaitu menghasilkan nilai MAPE sebesar 23,35. Sedangkan Metode Winter Multiplicative dan Winter Additive menghasilkan nilai MAPE masing masing 28,53\% dan 27,38\%.

2. Hasil prediksi dengan metode Triple Exponential Smoothing satu parameter menunjukan bahwa tingkat keakuratan model yang diperoleh lebih baik dengan hasil peramalan bulan Januari 2019 sebanyak 335 orang.

\section{Daftar Pustaka}

[1] W. . Stevenson dan S. . Chuong, Manajemen Operasi Perspektif Asia Edisi 9 Buku 1. Jakarta: Salemba Empat, 2015.

[2] D. Robert dan C. David, Hospitaly Marketing Management. New York: New York Wiley, 2001.

[3] T. Aprilianto dan I. Fauzi, "Perancangan Sistem Peramalan Penjualan Barang Pada UD Achmad Jaya Dengan Metode Triple Exponential Smoothing," J. Ilm. Teknol. Inf. STMIK ASIA Malang, vol. 10, no. 2, hal. 73-86, 2016.

[4] T. W. Utami dan M. Y. Darsyah, "PERAMALAN DATA SAHAM DENGAN MODEL WINTER'S," vol. 3, 2015 .

[5] M. Nasution, Manajemen mutu terpadu: total quality management. Bogor: Ghalia Indonesia, 2005.

[6] I. G. Hendrayana, "Sistem Peramalan Penjualan Barang Dengan Metode Single Exponential Smoothing Pada PT.Gieb Indonesia Cabang Denpasar,” 2018. 